\title{
Synthetic Studies of Ambruticin: Preparation of the C1-C8 Tetrahydropyran and the C17-C24 Dihydropyran Segments
}

\author{
Luping Liu ${ }^{1}$, Julie L. Wondergem (nee Lukesh) ${ }^{1,2}$, and William A. Donaldson ${ }^{1, *}$ \\ ${ }^{1}$ Department of Chemistry, Marquette University, P. O. Box 1881, Milwaukee, WI 53201-1881 USA \\ ${ }^{2}$ Present address: Division of Natural \& Applied Sciences, University of Wisconsin-Green Bay, \\ 2420 Nicolet Drive, Green Bay, WI 54311, USA
}

\begin{abstract}
The C1-C8 tetrahydropyran and the C17-C24 dihdropyran segments of ambruticin were prepared from L-arabinose in 11 steps, $7.6 \%$ overall yield and from $(S)$-ethyl lactate in 8 steps, $22.2 \%$ overall yield respectively.
\end{abstract}

Keywords: Natural products; $C$-glucosides; Oxonium ion; Cyclocondensation.

\section{Introduction}

Ambruticin (1, Fig. 1) is a structurally unique carboxylic acid isolated from Polyangium cellulosum var. fulvum which exhibits potent oral antifungal activity against Coccidioides immitis, Histoplasma capsulatum, and Blastomyces dermititidis 1. Extensive spectral analysis revealed that the structure of 1 consists of a tetrahydropyran ring, a dihydropyran ring, and a divinylcyclopropane ring. More recently the jerangolids A and D $(\mathbf{2 a}, \mathbf{b})$, isolated from a strain of Sorangium cellulosum (So ce 307), were found to exhibit antifungal activity similar to $\mathbf{1}^{2}$. The structure of 2 from C6-C17 is identical with the C13-C24 segment of ambruticin, and the similar antibiotic spectrum of $\mathbf{1}$ and $\mathbf{2}$ suggests that these segments are responsible for their biological activity. More over, the first four genes encoding for the polyketide synthesase for $\mathbf{1}$ and $\mathbf{2}$ are $>90 \%$ identical $^{3}$. The complex array of diverse functionality present in both $\mathbf{1}$ and $\mathbf{2}$ has generated considerable synthetic interest ${ }^{4}$, including total syntheses of 1 by the groups of Kende ${ }^{5}$, Jacobsen ${ }^{6}$, Martin $^{7}$, Lee ${ }^{8}$, and Hanessian ${ }^{9}$, and of $\mathbf{2 b}$ by Marko ${ }^{10}$ and $\mathbf{2} \mathbf{a}$ by Hanessian ${ }^{11}$.

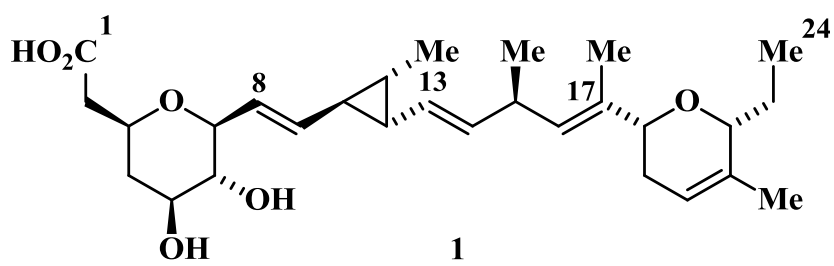<smiles>[R]CC1=C(OC)C[C@@H](/C=C/[C@H](C)/C=C(\C)[C@H]2CC=C(C)[C@@H](C[Y17])O2)OC1=O</smiles>

Figure 1. Structures of ambruticin (1) and the jerangolides (2a/b).

Our retrosynthetic analysis of $\mathbf{1}$ dissected the molecule at the $\mathrm{C} 8-\mathrm{C} 9$ and $\mathrm{C} 16-\mathrm{C} 17$ olefins into a cis-tetrahydropyran segment $\mathbf{3}$ and a cisdihydropyran segment 4 (Fig. 2). Notably, Just and Potvin confirmed the absolute configuration of ambruticin by preparation of $\mathbf{3}$ in optically active form, which they could compare to a sample obtained by degradation of $\mathbf{1}^{4 a}$. Addition syntheses of 3 are reported by the groups of Martin ${ }^{7}$, Lee ${ }^{8}$ and Michelet ${ }^{4 j}$. Furthermore, Martin ${ }^{7}$, Marko ${ }^{10}$, and Hanessian ${ }^{9,11}$ have prepared segment $\mathbf{4}$ as part of their syntheses of $\mathbf{1}$ and $\mathbf{2}$. We have previously reported the preparation of segments $\mathbf{3}$ and $\mathbf{4}$ in communication form ${ }^{12}$. We herein report the full experimental details for these syntheses. 
<smiles>O=C[C@H](O)[C@@H](O)[C@H](O)CO</smiles>

L-arabinose, 5

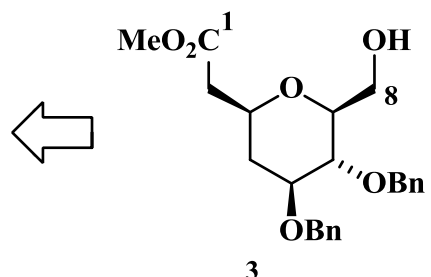<smiles>[Y4]C[C@H]1O[C@H](C(C)=O)CC=C1C</smiles><smiles>C1CCCCC1</smiles><smiles>CCOC(=O)C(C)O</smiles>

(S)-ethyl lactate, 6

Figure 2. Retrosynthetic analysis of segments $\mathbf{3}$ and $\mathbf{4}$ into chiral pool precursors.

\section{Results and Discussion}

We envisioned segments $\mathbf{3}$ and $\mathbf{4}$ arising via Cglycosylation of an in-situ generated oxonium cation with an appropriate weak carbon nucleophile ${ }^{13}$ (Fig. 3 ). These reactions are known to generally result in the formation of a trans-2,6-disubstituted tetrahydro- or dihydropyran due to the propensity for axial nucleophilic attack on the oxonium cation ${ }^{14}$. We rationalized that the trans-disubstituted products could subsequently be converted into the more thermodynamically stable cis-stereoisomers by epimerization.

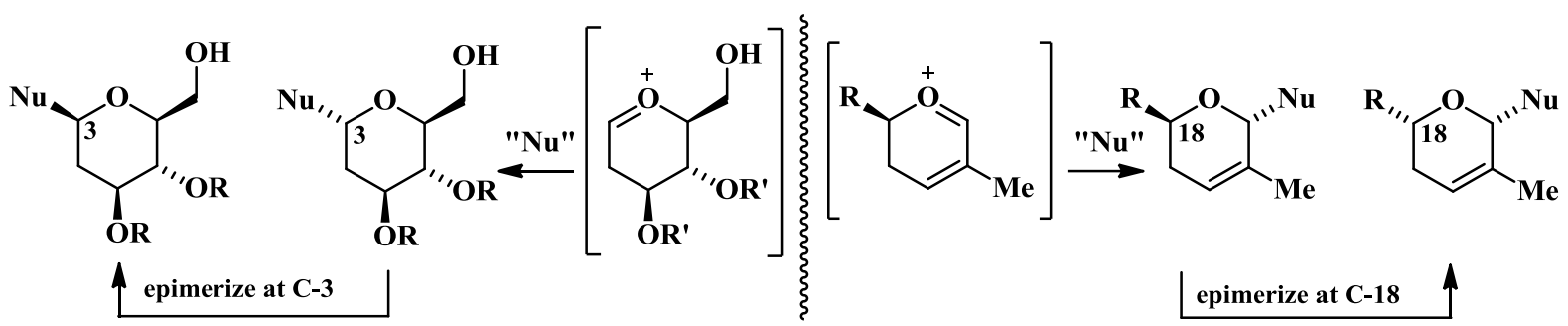

Figure 3. C-glycosylation and epimerization to cis-tetrahydro- and cis-dihydro-pyrans.

2,3-Di- $O$-benzyl-4,5-isopropylidene-1-arabinose 7 was prepared from L-arabinose $\mathbf{5}$ in 4 steps, $55 \%$ overall yield, via the literature procedure pa $^{4 \mathrm{a}}$. Attempted Wittig olefination of 7 with (methoxymethyl)triphenylphosphonium chloride using NaH/DMSO was unsuccessful and resulted in products which appear to arise from elimination. Alternatively, olefination of 7 with the ylide prepared using lithium diisopropylamine (LDA) proceeded in good yield to give $\mathbf{8}$ as a nearly equimolar mixture of $E$ - and $Z$-isomers (Scheme 1).

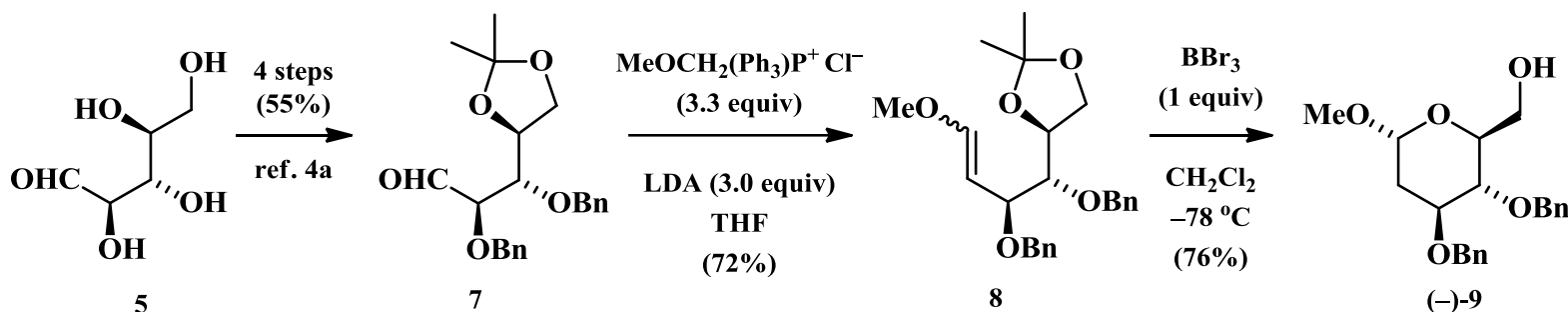

Scheme 1. Synthesis of the methyl 3,4-bis- $O$-benzyl-2-deoxy-L-glucose (-)-9.

Attempted hydrolysis of the enol ether $\mathbf{8}$ with aqueous acetic acid/p-TsOH gave an enal, due to elimination of a molecule of benzyl alcohol. Alternatively, cleavage of the 5,6-acetonide group of 8 with $\mathrm{BBr}_{3}$ proceeded with cyclization to the methyl glucoside (-)-9.

Ionization of the $\alpha$-methoxy group with $\mathrm{BF}_{3} \cdot \mathrm{Et}_{2} \mathrm{O}$ and subsequent nucleophilic attack with allyl trimethylsilane proceeded to give the tetrahydropyran (-)-10 (Scheme 2).

The trans-stereochemical assignment for $\mathbf{1 0}$ was based on its ${ }^{1} \mathrm{H}$ NMR spectral data. In particular, the signals H-4ax and H-4eq appear at $\delta 1.74$ and 2.01 ppm with a geminal coupling of $14.0 \mathrm{~Hz}$. However, the absence of a large coupling between H-4ax and $\mathrm{H}-3$ indicates that $\mathrm{H}-3$ occupies an equatorial position. Ozonolysis of $\mathbf{1 0}$ in methanol, followed by reductive workup with dimethyl sulfide gave the corresponding aldehyde (-)-11. Notably, use of $\mathrm{CH}_{2} \mathrm{Cl}_{2}$ for solvent in this ozonolysis proceeded in poor yields. Aldehyde $\mathbf{1 1}$ underwent oxidation to the carboxylic acid slowly under a stream of air; this oxidation was more rapid in diethyl ether/methanol containing a catalytic amount of sodium methoxide. Due to difficulties in purification of the corresponding carboxylic acid, an alternative route utilized pyridinium dichromate in DMF containing 2.5\% methanol to afford the ester $\mathbf{1 2}$ in high yield, 
presumably via the hemiacetal. Treatment of $\mathbf{1 2}$ with sodium methoxide in methanol/water/toluene proceeded to afford the cis-tetrahydropyran carboxylic acid 13. This product arises via an elimination/addition reaction to equilibrate the less stable $\mathbf{1 2}$ to the more stable $\mathbf{3}$, followed by saponification (Scheme 3). Diimide mediated coupling of 13 with methanol gave the C1-C8 tetrahydropyran segment (-)-3. The cis- stereochemical assignment for $\mathbf{3}$ was based on its ${ }^{1} \mathrm{H}$ NMR spectral data. In particular, the signals $\mathrm{H}-4 \mathrm{ax}$ appears as a quartet $(J=12.5 \mathrm{~Hz})$ at $\delta 1.42 \mathrm{ppm}$. The large magnitude of these couplings are attributed to geminal coupling to $\mathrm{H}-4 \mathrm{eq}$, as well as trans-diaxial couplings to $\mathrm{H}-3$ and $\mathrm{H}-5$. By this route, the $\mathrm{C} 1-\mathrm{C} 8$ segment (-)-3 was prepared from L-arabinose in 11 steps and $7.6 \%$ overall yield.

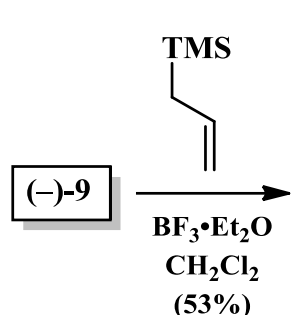

$(53 \%)$<smiles>C=CC[C@]1(C)OC(CO)[C@H](OC)[C@H](O)[C@H]1O</smiles>

$(-)-10$

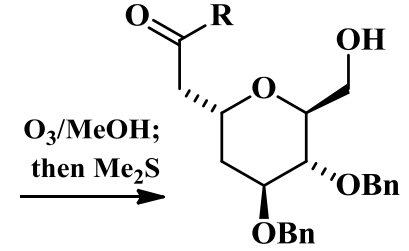

$\underset{\text { DMF }}{\mathrm{PDC} / \mathrm{MeOH}}\left(\begin{array}{c}(-)-11, \mathrm{R}=\mathrm{H}(82 \%) \\ 12, \mathrm{R}=\text { OMe }(91 \%)\end{array}\right.$
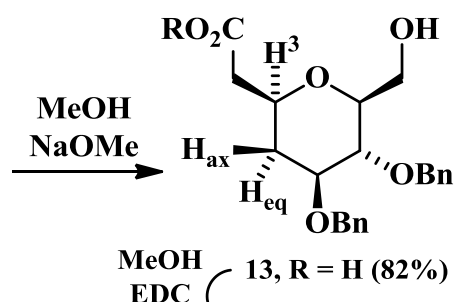

HOBT $-(-)-3, R=\operatorname{Me}(77 \%)$

Scheme 2. Synthesis of the C1-C8 segment (-)-3.

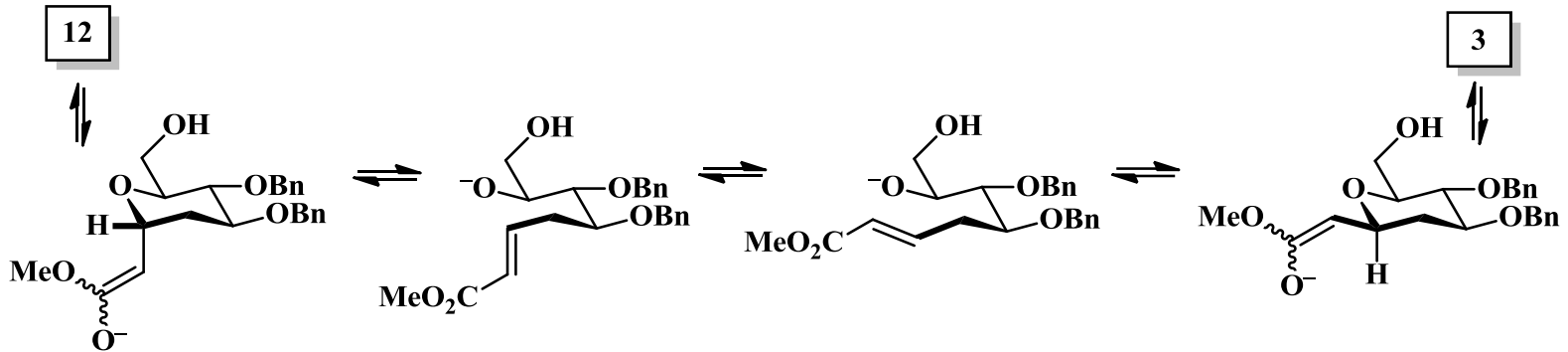

Scheme 3. Epimerization of trans-12 to cis-3.

Construction of dihydropyran $\mathbf{4}$ was envisioned by means of a Lewis acid catalyzed diene-aldehyde cyclocondensation reaction ${ }^{15}$. To this end, 2(S)benzyloxypropanal (14) was prepared from (S)-ethyl lactate (6) in two steps, $73 \%$ overall yield, by the literature procedure ${ }^{16}$. Reaction of 14 with 1methoxy-2-methyl-3-(trimethylsiloxy)-1,3-butadiene (15) ${ }^{17}$ in the presence of $\mathrm{BF}_{3} \cdot \mathrm{Et}_{2} \mathrm{O}$, followed by work-up with trifluoroacetic acid gave an inseparable mixture of diastereomeric dihydropyrones $\mathbf{1 6}$ and $\mathbf{1 7}$ in a 1.6:1 ratio (Scheme 4). The structural assignments of $\mathbf{1 6}$ and $\mathbf{1 7}$ were based on comparison of their ${ }^{1} \mathrm{H}$ NMR spectral data. In particular, the signals for $\mathrm{H}-17$ and $\mathrm{H}-19 \mathrm{eq}$ (ambruticin numbering)

(S)-ethyl lactate (6)<smiles>C=C(O[Na])C(C)=COC</smiles><smiles>[Y4]C1=CO[C@@H]([C@@](C)(O)[C@H](C)O)CC1=O</smiles>

$$
16
$$$$
16 \quad(+)-17
$$

$\mathrm{BF}_{3} \cdot \mathrm{OEt}_{2} / \mathrm{CH}_{2} \mathrm{Cl}_{2} /-78^{\circ} \mathrm{C}$ to $23^{\circ} \mathrm{C}$ $\mathrm{MgBr}_{2} / \mathrm{THF} / 0^{\circ} \mathrm{C}$ to $23^{\circ} \mathrm{C}$ of 17 ( $\delta 3.69$ and $2.36 \mathrm{ppm}$ respectively) appear upfield of the corresponding signals for $\mathbf{1 6}(\delta 3.81$ and $2.56 \mathrm{ppm}$ respectively). These relative chemical shifts are quite characteristic of diastereomeric dihydropyrones with an $\alpha$-benzyloxy group (Figure 4) ${ }^{18}$. Use of $\mathrm{MgBr}_{2}$ as Lewis acid (instead of $\mathrm{BF}_{3} \cdot \mathrm{Et}_{2} \mathrm{O}$ ) in the cyclocondensation reaction gave only 17 after acidic workup. The exclusive formation of 17 under $\mathrm{MgBr}_{2}$ mediated conditions is the result of approach of the diene in an exo sense on the less hindered face of $\mathrm{a} \mathrm{Mg}^{2+}$ chelated form of aldehyde 14 (see insert, Scheme 3).

Scheme 4. Aldehyde-silyloxy diene cyclocondensation. 


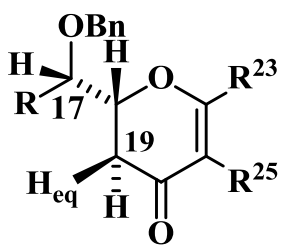

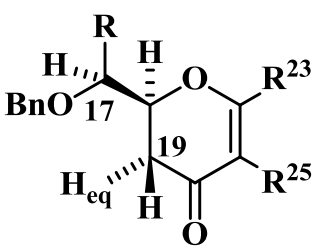

$\begin{array}{cccccccccc}\underline{\mathrm{H}}^{17} & \underline{\mathrm{H}}^{19 \mathrm{eq}} & & \underline{\mathrm{R}} & \underline{\mathrm{R}}^{25} & \underline{\mathrm{R}}^{23} & & \underline{\mathrm{H}}^{17} & \underline{\mathrm{H}}^{19 \mathrm{eq}} & \underline{\text { ref. }} \\ \delta 3.48 & \delta 2.27 & \mathbf{1 8 a} & \mathrm{Me} & \mathrm{H} & \mathrm{Et} & \mathbf{1 9 a} & \delta 3.68 & \delta 2.44 & 18 \\ \delta 3.72 & \delta 2.40 & \mathbf{1 8 b} & \mathrm{H} & \mathrm{H} & \mathrm{Me} & \mathbf{1 9 b} & \delta 3.82 & \delta 2.53 & 18 \\ \delta 3.69 & \delta 2.36 & \mathbf{1 6} & \mathrm{H} & \mathrm{Me} & \mathrm{Me} & \mathbf{1 7} & \delta 3.81 & \delta 2.56 & \text { this work }\end{array}$

Figure 4. Characteristic proton chemical shifts of diastereomeric dihydropyrones.

Pyranone 17 underwent reduction with DIBAL via axial addition of hydride to give the pseudoglycal (+)-20 as a single diastereomer (Scheme 5). Reaction of pseudoglycal $\mathbf{2 0}$ with the weak nucleophile triethylaluminum, in the presence of $\mathrm{BF}_{3} \bullet \mathrm{Et}_{2} \mathrm{O}$, gave a mixture of trans- and cis-dihydropyrans (8:1 ratio). The major diastereomer (-)-21, was obtained in good yield after column chromatography, and its structure was tentatively based on previous results from our laboratory as well as others on $C$-glycosidation reactions with trialkylaluminum ${ }^{19}$. Eventual

$(+)-17$

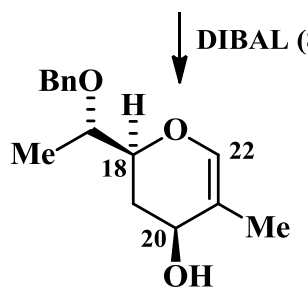

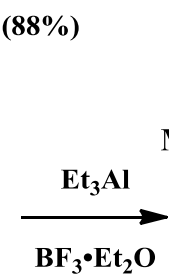<smiles>[Y4]C[C@H]1O[C@@H]([C@H]([R20])C)CC=C1C</smiles>

transformation of $\mathbf{2 1}$ into known (+)-4 corroborated this tentative assignment. Removal of the benzyl protecting group under dissolving metal conditions, followed by oxidation gave (-)-23. Base-catalyzed epimerization of the trans-ketone, in benzene, gave a separable mixture of $\mathbf{2 3}$ and 4 (1:2 ratio). Two equilibration/separation cycles gave pure (+)-4 in $83 \%$ combined yield. By this route, the C17-C24 segment (+)-4 was prepared from $(S)$-ethyl lactate in 8 steps and $22.2 \%$ overall yield.

(+)-20

$$
\begin{array}{cc}
\mathrm{Na} / \mathrm{NH}_{3} \\
\mathrm{THF}
\end{array} \quad \begin{gathered}
(-)-21, \mathrm{R}=\mathrm{Bn}(75 \%) \\
(-)-22, \mathrm{R}=\mathrm{H}(81 \%)
\end{gathered}
$$

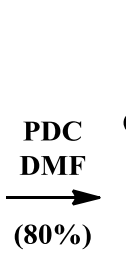<smiles>[Y10]C[C@H]1O[C@H](C(C)=O)CC=C1C</smiles>

$\mathrm{K}_{2} \mathrm{CO}_{3}$ (23:4=1:2) separable

$83 \%$ pure 4 after two equilibration/separation cycles

Scheme 5. Synthesis of dihydropyran segment 4.

\section{Conclusion}

The synthesis of the tetrahydropyran and dihydropyran segments of ambruticin were prepared from chiral pool precursors. The C1-C8 segment, ()-3, was prepared from L-arabinose in 11 steps, 7.6\% overall yield and the C17-C24 segment, (+)-4, was prepared from $(S)$-ethyl lactate in 8 steps, $22.2 \%$ overall yield. In both cases, the synthetic strategy relied on $C$-glycosylation followed by epimerization to the more stable cis-stereoisomers.

\section{Acknowledgements}

Partial financial support for this research was provided by the National Institutes of Health (GM42641), the Department of Education (P200A000228), and the Marquette University Graduate School Committee on Research. High resolution mass spectral data were obtained at the Washington University Resource for Mass Spectrometry.

\section{Experimental Section}

$\mathrm{H}$ and ${ }^{13} \mathrm{C}$ NMR spectra were recorded at 300 $\mathrm{MHz}$ and $75 \mathrm{MHz}$ respectively unless otherwise indicated. High-resolution mass spectra were obtained from the Washington University Resource for Biomedical and Bioorganic mass spectrometry. Tetrahydrofuran was distilled from sodium benzophenone ketyl prior to use. Anhydrous $\mathrm{CH}_{2} \mathrm{Cl}_{2}$ and anhydrous DMF were purchased from Aldrich Chemical Company. Reactions were performed in flame-dried glassware under an atmosphere of $\mathrm{N}_{2}$ unless otherwise noted. Compounds $7^{4 \mathrm{a}}, 14^{16}$, and $15^{17}$ were prepared by literature procedures.

2-Deoxy-1- $O$-methyl-5,6- $O$-(1methylethylidene)-3,4-bis- $O$-(phenylmethyl)-Larabino-hex-1-enitol (8).

To solution of (methoxymethyl)triphenylphosphonium chloride $(1.45 \mathrm{~g}, 4.24 \mathrm{mmol})$ in anhydrous THF $(10 \mathrm{~mL})$ under nitrogen at $-78{ }^{\circ} \mathrm{C}$ was added a solution of 
lithium diisopropylamine $(1.5 \mathrm{~mL}, \quad 2.0 \quad \underline{\mathrm{M}}$ in benzene/THF, $3.0 \mathrm{mmol}$ ). The mixture was stirred for $30 \mathrm{~min}$. A solution of $7(0.477 \mathrm{~g}, 1.29 \mathrm{mmol})$ in anhydrous THF $(5 \mathrm{~mL})$, pre-cooled to $-78{ }^{\circ} \mathrm{C}$, was added over a period of $10 \mathrm{~min}$. After completion of the addition, the reaction mixture was warmed to room temperature and stirred for $20 \mathrm{~min}$. The reaction mixture was diluted with ice-water, extracted several times with diethyl ether, and the combined extracts were washed with water, followed by brine, dried $\left(\mathrm{MgSO}_{4}\right)$ and concentrated. The residue was purified by column chromatography $\left(\mathrm{SiO}_{2}\right.$, hexanes-ethyl acetate $\left.=9: 1\right)$, to give a mixture of E/Z-isomers $8(0.37 \mathrm{~g}, 72 \%)$ as a light yellow oil; $[\alpha]_{\mathrm{D}}^{23}-21\left(\mathrm{c}=0.91, \mathrm{CHCl}_{3}\right)$. IR (neat): 2979, 2958, 2916, 2870, 1609, 1598, 1465, 1443, 1330, 1259, 1098, $967 \mathrm{~cm}^{-1} .{ }^{1} \mathrm{H}$ NMR $\left(\mathrm{CDCl}_{3}\right): \delta=7.27-7.39$ $(\mathrm{m}, 10 \mathrm{H}), 6.47(\mathrm{~d}, J=13.0 \mathrm{~Hz}, \quad 0.58 \mathrm{H}$, $\mathrm{C}=\mathrm{CH}(\mathrm{OMe})), \quad 6.10 \quad(\mathrm{~d}, \quad J=6.0 \mathrm{~Hz}, \quad 0.42 \mathrm{H}$, $\mathrm{C}=\mathrm{CH}(\mathrm{OMe})), 3.73-4.84(\mathrm{~m}, 9 \mathrm{H}), 3.62(\mathrm{~s}, 1.3 \mathrm{H}$, $\mathrm{OMe}), 3.53(\mathrm{~s}, 1.7 \mathrm{H}, \mathrm{OMe}), 1.42(\mathrm{~s}, 3 \mathrm{H}), 1.34$ $\left(\mathrm{s}, 3 \mathrm{H}\right.$ ). MS (FAB/KI) $\mathrm{m} / \mathrm{z} 437$ (calcd for $\mathrm{C}_{24} \mathrm{H}_{30} \mathrm{O}_{5} \mathrm{~K}$ $\left[\mathrm{M}+\mathrm{K}^{+}\right] \mathrm{m} / \mathrm{z}$ 437).

Methyl 2-deoxy-3,4-bis- $O$-(phenylmethyl)- $\alpha$ L-arabino-hexopyranoside ((-)-9).

To a solution of $8(2.52 \mathrm{~g}, 6.33 \mathrm{mmol})$ in $\mathrm{CH}_{2} \mathrm{Cl}_{2}$ $(50 \mathrm{~mL})$ at $-78{ }^{\circ} \mathrm{C}$ was slowly added a solution of $\mathrm{BBr}_{3}\left(0.65 \mathrm{~mL}, 1.0 \underline{\mathrm{M}}\right.$ in $\left.\mathrm{CH}_{2} \mathrm{Cl}_{2}, 0.65 \mathrm{mmol}\right)$. The color of the reaction solution immediately changed from light yellow to darkness and heat was released when the $\mathrm{BBr}_{3}$ was added. After completion of addition, the reaction solution was gradually warmed to room temperature and stirred for $30 \mathrm{~min}$. The reaction mixture was diluted with diethyl ether and washed with saturated aqueous $\mathrm{NaHCO}_{3}$, followed by water, and brine, dried $\left(\mathrm{MgSO}_{4}\right)$, and concentrated. The residue was purified by column chromatography $\left(\mathrm{SiO}_{2}\right.$, hexanes-acetone $\left.=9: 1\right)$ to give (-)-9 (1.72 g, 76\%) as a pale oil; $[\alpha]_{\mathrm{D}}^{23}-54.0$ (c $\left.=0.78, \mathrm{CHCl}_{3}\right)$ [for D-enantiomer lit. ${ }^{20}[\alpha]_{\mathrm{D}}{ }^{30}=$ +69 (c 0.43, $\left.\left.\mathrm{CHCl}_{3}\right)\right]$. IR (neat): 3600-3200, 3085, $3060,3035,2983,2910,1720,1454,1365,1207$ 1127, 1098, 1050, 1028, $987 \mathrm{~cm}^{-1} . \quad{ }^{1} \mathrm{H} \quad \mathrm{NMR}$ $\left(\mathrm{CDCl}_{3}\right): \delta=7.39-7.27(\mathrm{~m}, 10 \mathrm{H}), 4.95(\mathrm{~d}, J=11.0$ $\mathrm{Hz}, 1 \mathrm{H}), 4.80(\mathrm{~d}, J=3.0 \mathrm{~Hz}, 1 \mathrm{H}), 4.71-4.62(\mathrm{~m}, 3 \mathrm{H})$, 4.04-3.94 (m, 1H), 3.83-3.71 (m, 2H), $3.64(\mathrm{dt}, J=$ $10.0,4.0 \mathrm{~Hz}, 1 \mathrm{H}), 3.50(\mathrm{t}, J=12.0 \mathrm{~Hz}, 1 \mathrm{H}), 3.31$ (s, 3H), $2.30(\mathrm{ddd}, J=12.0,4.5,1.5 \mathrm{~Hz}, 1 \mathrm{H}), 1.78$ $(\mathrm{dd}, J=7.5,6.0 \mathrm{~Hz}, 1 \mathrm{H}), 1.65$ (ddd, $J=12.0,10.0$, $4.0 \mathrm{~Hz}, 1 \mathrm{H}) .{ }^{1} \mathrm{H}$ NMR spectral data for this compound was consistent with the literature values for the D-enantiomer ${ }^{20}$. MS (DCI/ $\left.\mathrm{NH}_{3}\right) \mathrm{m} / z \quad 376$ (calcd for $\mathrm{C}_{21} \mathrm{H}_{26} \mathrm{O}_{5} \bullet \mathrm{NH}_{4},\left[\mathrm{M}+\mathrm{NH}_{4}^{+}\right] \mathrm{m} / z$ 376).

4,8-Anhydro-1,2,3,5-tetradeoxy-6,7-bis- $O$ (phenylmethyl)-L-manno-non-1-enitol ((-)-10).

A solution of $9(1.01 \mathrm{~g}, 2.82 \mathrm{mmol})$ and allyl trimethylsilane $(1.00 \mathrm{~g}, 8.76 \mathrm{mmol})$ in $\mathrm{CH}_{2} \mathrm{Cl}_{2}$ $(30 \mathrm{~mL})$ at $0{ }^{\circ} \mathrm{C}$ was treated with $\mathrm{BF}_{3} \cdot \mathrm{Et}_{2} \mathrm{O}$ (0.85 mL, $0.98 \mathrm{~g}, 6.96 \mathrm{mmol})$.
The color of the reaction mixture changed from light yellow to darkness immediately after adding the Lewis acid. The reaction solution was stirred at $0{ }^{\circ} \mathrm{C}$ for $30 \mathrm{~min}$ under nitrogen. The mixture was diluted with diethyl ether, followed by slow addition of saturated aqueous $\mathrm{NaHCO}_{3}$. The organic layer was separated and washed with saturated aqueous $\mathrm{NaHCO}_{3}$, followed by water, and brine, dried $\left(\mathrm{MgSO}_{4}\right)$, and concentrated. The residue was purified by column chromatography $\left(\mathrm{SiO}_{2}\right.$, hexanesacetone $=9: 1)$ to give (-)-10 as an oil $(0.552 \mathrm{~g}$, $53 \%) ;[\alpha]_{\mathrm{D}}{ }^{23}-36.4 \quad\left(\mathrm{c}=0.87, \mathrm{CHCl}_{3}\right)$. IR (neat): 3600-3200, 3065, 3030, 2926, 2874, 1454, 1365, 1209, 1099, 1048, 1028, $999 \mathrm{~cm}^{-1} . \quad{ }^{1} \mathrm{H}$ NMR $\left(\mathrm{CDCl}_{3}\right): \delta=7.27-7.39(\mathrm{~m}, 10 \mathrm{H}), 5.82-5.67(\mathrm{~m}, 1 \mathrm{H})$, $5.18-5.01(\mathrm{~m}, 2 \mathrm{H}), 4.85(\mathrm{~d}, J=11.0 \mathrm{~Hz}, 1 \mathrm{H}), 4.65-$ $4.41(\mathrm{~m}, 3 \mathrm{H}), 3.59-3.86(\mathrm{~m}, 4 \mathrm{H}), 4.08-3.99(\mathrm{~m}, 1 \mathrm{H})$, $3.43(\mathrm{t}, J=7.0 \mathrm{~Hz}, 1 \mathrm{H}), 2.46$ (pent of d, $J=7.0,1.0$ $\mathrm{Hz}, 1 \mathrm{H}$ ), 2.11 (pent, $J=7.0 \mathrm{~Hz}, 1 \mathrm{H}), 2.01$ (dt, $J=$ 14.0, 4.5 Hz, 1H), 1.92 (t, $J=7.0 \mathrm{~Hz}, 1 \mathrm{H}), 1.80-1.69$ $(\mathrm{m}, 1 \mathrm{H}) .{ }^{13} \mathrm{C} \mathrm{NMR}\left(\mathrm{CDCl}_{3}\right): \delta=138.3,138.2$, 134.4, 128.4, 128.0, 127.8, 127.7, 117.3, 77.6, 76.5, 74.3, 73.2, 71.4, 70.7, 62.3, 36.6, 32.7. FAB-HRMS $\mathrm{m} / \mathrm{z} 369.2065$ (calcd for $\mathrm{C}_{23} \mathrm{H}_{29} \mathrm{O}_{4}\left[\mathrm{M}+\mathrm{H}^{+}\right] \mathrm{m} / \mathrm{z}$ 369.2066).

\section{3,7-Anhydro-2,4-dideoxy-5,6-bis- $O$ -} (phenylmethyl)-L-manno-octose (-)-11.

A solution of $\mathbf{1 0}(0.552 \mathrm{~g}, 1.50 \mathrm{mmol})$ in methanol $(10 \mathrm{~mL})$ was cooled to $-78{ }^{\circ} \mathrm{C}$ in a dry ice/acetone bath. The system was purged with carrier gas (compressed air) for $20 \mathrm{~min}$ and then ozone (generated from compressed air with a Welsbach apparatus) was bubbled through the solution until a blue color persisted. The system was purged with carrier gas until the blue color disappeared. Dimethyl sulfide $(0.5 \mathrm{~mL})$ and water $(0.2 \mathrm{~mL})$ were added to the reaction mixture and this was stirred for $3 \mathrm{~h}$. After concentration in vacuo, the reaction mixture was diluted with diethyl ether and water. The organic layer was separated and washed with water, followed by brine, dried $\left(\mathrm{MgSO}_{4}\right)$ and concentrated. The residue was purified by column chromatography $\left(\mathrm{SiO}_{2}\right.$, hexane-acetone $\left.=13: 7\right)$, to give (-)-11 $(0.455 \mathrm{~g}, 82 \%)$ as an oil; $[\alpha]_{\mathrm{D}}{ }^{23}-10.5$ (c $\left.=1.27, \mathrm{CHCl}_{3}\right)$. IR (neat): 3600-3200, 3085, 3060, 3035, 2926, 2876, 1723, 1497, 1454, 1365, 1314, 1270, 1208, 1097, $1028 \mathrm{~cm}^{-1} .{ }^{1} \mathrm{H}$ NMR $\left(\mathrm{CDCl}_{3}\right): \delta=9.76(\mathrm{t}, J=1.0 \mathrm{~Hz}, 1 \mathrm{H}, \mathrm{CHO}), 7.39$ $7.26(\mathrm{~m}, 10 \mathrm{H}), 4.72(\mathrm{~d}, J=12.0 \mathrm{~Hz}, 1 \mathrm{H}), 4.62(\mathrm{~d}, J=$ $12.0 \mathrm{~Hz}, 1 \mathrm{H}), 4.66-4.53(\mathrm{~m}, 3 \mathrm{H}), 4.04(\mathrm{dd}, J=12.0$, $7.0 \mathrm{~Hz}, 1 \mathrm{H}), 3.81-3.73(\mathrm{~m}, 2 \mathrm{H}), 3.59(\mathrm{dd}, J=12.0$, $4.0 \mathrm{~Hz}, 1 \mathrm{H}), 3.39$ (t, $J=6.0 \mathrm{~Hz}, 1 \mathrm{H}), 2.84$ (ddd, $J=$ 17.0, 9.0, 2.0 Hz, 1H), 2.52 (ddd, $J=17.0,4.5,1.0$ $\mathrm{Hz}, 1 \mathrm{H}), 2.00-1.91(\mathrm{~m}, 1 \mathrm{H}), 1.83-1.73(\mathrm{~m}, 1 \mathrm{H})$; signal for $\mathrm{OH}$ not observed. ${ }^{13} \mathrm{C} \mathrm{NMR}\left(\mathrm{CDCl}_{3}\right)$ : $\delta=200.0,138.0,128.5,127.9,127.8,127.6,74.90$, $74.85,73.3,71.5,63.5,61.0,47.2,32.4$. MS $\left(\mathrm{DCI} / \mathrm{NH}_{3}\right) \quad m / z \quad 388$ (calcd for $\mathrm{C}_{22} \mathrm{H}_{26} \mathrm{O}_{5} \bullet \mathrm{NH}_{4}$ $\left[\mathrm{M}+\mathrm{NH}_{4}{ }^{+}\right] \mathrm{m} / \mathrm{z}$ 388). 
Methyl 3,7-anhydro-2,4-dideoxy-5,6-bis- $O$ (phenylmethyl)-L-manno-octanoate (12).

To a solution of $11(0.386 \mathrm{~g}, 1.04 \mathrm{mmol})$ in DMF (4 mL) containing methanol $(0.1 \mathrm{~mL})$ was added pyridinium dichromate $(0.453 \mathrm{~g}, 1.20 \mathrm{mmol})$. The mixture was stirred at room temperature for $2 \mathrm{~h}$, and then heated at $50{ }^{\circ} \mathrm{C}$ overnight. After cooling, the mixture was diluted with diethyl ether and water. The organic layer was separated and washed with 1 $\underline{\mathrm{N}}$ aqueous $\mathrm{HCl}$, followed by saturated aqueous $\mathrm{NaHCO}_{3}$, water, and brine, dried $\left(\mathrm{MgSO}_{4}\right)$ and concentrated. The residue was purified by column chromatography $\left(\mathrm{SiO}_{2}\right.$, hexanes-acetone $\left.=13: 7\right)$, to give $12(0.381 \mathrm{~g}, 91 \%)$ as a colorless oil. ${ }^{1} \mathrm{H}$ NMR $\left(\mathrm{CDCl}_{3}\right): \delta=7.39-7.27(\mathrm{~m}, 10 \mathrm{H}), 4.71(\mathrm{~d}, J=12.0$ $\mathrm{Hz}, 1 \mathrm{H}), 4.61(\mathrm{~d}, J=12.0 \mathrm{~Hz}, 1 \mathrm{H}), 4.55-4.39(\mathrm{~m}$, $3 \mathrm{H}), 4.08$ (ddd, $J=12.0,7.5,4.0 \mathrm{~Hz}, 1 \mathrm{H}), 3.88-3.74$ $(\mathrm{m}, 2 \mathrm{H}), 3.69$ (s, 3H), $3.53(\mathrm{ddd}, J=12.0,9.0,3.0$ $\mathrm{Hz}, 1 \mathrm{H}), 3.34$ (t, $J=5.0 \mathrm{~Hz}, 1 \mathrm{H}), 2.68(\mathrm{dd}, J=16.5$, $10.0 \mathrm{~Hz}, 1 \mathrm{H}), 2.43(\mathrm{dd}, J=16.5,7.5 \mathrm{~Hz}, 1 \mathrm{H}), 2.01$ $1.91(\mathrm{~m}, 1 \mathrm{H}), 1.81-1.72(\mathrm{~m}, 1 \mathrm{H})$; signal for $\mathrm{OH}$ not observed. ${ }^{13} \mathrm{C}$ NMR $\left(\mathrm{CDCl}_{3}\right): \delta=193.5,138.0$ 128.6, 127.9, 127.8, 127.6, 75.1, 74.9, 73.1, 71.5, 65.1, 60.8, 52.0, 38.3, 32.2. FAB-HRMS $\mathrm{m} / \mathrm{z}$ 401.1963 (calcd for $\mathrm{C}_{23} \mathrm{H}_{29} \mathrm{O}_{5} \quad\left[\mathrm{M}+\mathrm{H}^{+}\right] \quad \mathrm{m} / \mathrm{z}$ 401.1964).

Methyl 3,7-anhydro-2,4-dideoxy-5,6-bis- $O$ (phenylmethyl)-L-gluco-octanoate ((-)-3).

To a solution of $12(0.381 \mathrm{~g}, 0.0953 \mathrm{mmol})$ in toluene $(2 \mathrm{~mL})$ was added $25 \%$ methanolic $\mathrm{NaOMe}$ $(0.2 \mathrm{~mL})$. The color of the reaction mixture changed from colorless to yellow immediately upon addition. The reaction mixture was stirred at $60{ }^{\circ} \mathrm{C}$ for $6 \mathrm{~h}$ in an open flask. Half of the solvent was evaporated during the reaction and some white precipitate was observed. The reaction mixture was partitioned between ethyl acetate and $1 \underline{\mathrm{N}} \mathrm{HCl}$. The organic layer was separated, and the aqueous layer was extracted several times with ethyl acetate. The combined organic layers were washed with $1 \underline{\mathrm{N}} \mathrm{HCl}$, then water, followed by brine, dried $\left(\mathrm{MgSO}_{4}\right)$ and concentrated to give $\mathbf{1 3}$ as an oil $(0.301 \mathrm{~g}, 82 \%)$. This compound was used in the next step without further characterization. To a solution of $\mathbf{1 3}(0.155$ $\mathrm{g}, \quad 0.040 \mathrm{mmol})$ in $\mathrm{CH}_{2} \mathrm{Cl}_{2}(1 \mathrm{~mL})$ at room temperature was added methanol $(0.2 \mathrm{~mL})$, ethyl dimethylaminopropyl carbodiimide hydrochloride $(0.211 \mathrm{~g}, 0.11 \mathrm{mmol})$ and 1-hydroxy-benzotriazole hydrate $(0.058 \mathrm{~g}, 0.043 \mathrm{mmol})$ and the mixture was stirred overnight. The reaction mixture was diluted with diethyl ether and water, the layers were separated and the aqueous layer was extracted several times with diethyl ether. The combined organic layers were washed with water, followed by brine, dried $\left(\mathrm{MgSO}_{4}\right)$ and concentrated. The residue was purified by column chromatography $\left(\mathrm{SiO}_{2}\right.$, hexanes-acetone $=9: 1)$, to give $(-)-3(0.124 \mathrm{~g}, 77 \%)$ as an oil. $[\alpha]_{\mathrm{D}}{ }^{23}-9.6\left(\mathrm{c}=0.73, \mathrm{CHCl}_{3}\right) ;+3.27$ (c $=0.98,95 \%$ ethanol); ${ }^{1} \mathrm{H}$ NMR $(500 \mathrm{MHz}$, $\left.\mathrm{CDCl}_{3}\right): \delta=7.39-7.28(\mathrm{~m}, 10 \mathrm{H}), 4.95(\mathrm{~d}, J=11.0$
$\mathrm{Hz}, 1 \mathrm{H}), 4.71(\mathrm{~d}, J=12.0 \mathrm{~Hz}, 1 \mathrm{H}), 4.68(\mathrm{~d}, J=11.0$ $\mathrm{Hz}, 1 \mathrm{H}), 4.64(\mathrm{~d}, J=11.0 \mathrm{~Hz}, 1 \mathrm{H}), 3.93-3.85$ $(\mathrm{m}, 1 \mathrm{H}), 3.83(\mathrm{dd}, J=12.0,3.0 \mathrm{~Hz}, 1 \mathrm{H}), 3.70$ (s, 3H), 3.75-3.65 (m, 2H), $3.44(\mathrm{t}, J=10.0 \mathrm{~Hz}, 1 \mathrm{H})$, $3.36-3.31(\mathrm{~m}, 1 \mathrm{H}), 2.62(\mathrm{dd}, J=16.0,7.0 \mathrm{~Hz}, 1 \mathrm{H})$, 2.46 (dd, $J=16.0,6.0 \mathrm{~Hz}, 1 \mathrm{H}), 2.24$ (ddd, $J=12.5$, 6.0, $3.0 \mathrm{~Hz}, 1 \mathrm{H}), 1.42(\mathrm{q}, J=12.5 \mathrm{~Hz}, 1 \mathrm{H})$; signal for $\mathrm{OH}$ not observed. ${ }^{13} \mathrm{C} \mathrm{NMR}\left(\mathrm{CDCl}_{3}\right) \delta 171.1$, 138.4, 138.3, 128.4, 128.0, 127.7, 127.6, 80.5, 79.0, $78.2,75.0,71.8,71.5,62.4,51.7,40.4,36.6$. FABHRMS $m / z 401.1963$ (calcd for $\mathrm{C}_{23} \mathrm{H}_{29} \mathrm{O}_{5}\left[\mathrm{M}+\mathrm{H}^{+}\right]$ $\mathrm{m} / \mathrm{z}$ 401.1964).

(2S)-2,3-Dihydro-5-methyl-2-[(1S)-1(phenylmethoxy)ethyl]-4H-pyran-4-one ((+)-17).

To a solution of $14(1.27 \mathrm{~g}, 7.74 \mathrm{mmol})$ in dry THF $(30 \mathrm{~mL})$ at $0{ }^{\circ} \mathrm{C}$ was added a freshly prepared ethereal solution of $\mathrm{MgBr}_{2}$ (4.0 mL, $2.2 \mathrm{M}$, prepared from 1,2-dibromoethane and magnesium turnings). This solution was stirred at $0{ }^{\circ} \mathrm{C}$ for $10 \mathrm{~min}$ and then a solution of $\mathbf{1 5}$ (3.04 g, $15.3 \mathrm{mmol})$ in dry THF (30 $\mathrm{mL}$ ) was added. The reaction mixture was slowly warmed to room temperature. After $14 \mathrm{~h}$ the reaction mixture was washed with saturated aqueous $\mathrm{NaHCO}_{3}$ and the combined aqueous layers were extracted several times with ether. The combined extracts were dried $\left(\mathrm{MgSO}_{4}\right)$ and concentrated. The black residue was dissolved in $\mathrm{CH}_{2} \mathrm{Cl}_{2}(75 \mathrm{~mL})$ and treated with trifluoroacetic acid $(4 \mathrm{~mL})$. The reaction mixture was stirred at room temperature in air for $3 \mathrm{~h}$ and was then washed with saturated aqueous $\mathrm{NaHCO}_{3}$ and the combined aqueous layers were extracted several times with $\mathrm{CH}_{2} \mathrm{Cl}_{2}$. The organic layers were dried $\left(\mathrm{MgSO}_{4}\right)$, concentrated, and the residue was purified by column chromatography $\left(\mathrm{SiO}_{2}\right.$, hexanes-ethyl acetate $\left.=5: 1\right)$ to give $(+)-17(1.64 \mathrm{~g}, 86 \%)$ as a yellow oil: $[\alpha]_{\mathrm{D}}{ }^{23}$ +120 (c 0.330, $\mathrm{CHCl}_{3}$ ). IR (neat): 2976, 2928, 2893, $1668,1621,1455,1379,1299,1165,1104 \mathrm{~cm}^{-1} \cdot{ }^{1} \mathrm{H}$ NMR $\left(\mathrm{CDCl}_{3}\right): \delta=7.39-7.28(\mathrm{~m}, 6 \mathrm{H}), 4.70(\mathrm{~d}, J=$ $11.7 \mathrm{~Hz}, 1 \mathrm{H}), 4.53(\mathrm{~d}, J=11.7 \mathrm{~Hz}, 1 \mathrm{H}), 4.34$ (ddd, $J$ $=14.7,3.8,3.6 \mathrm{~Hz}, 1 \mathrm{H}), 3.69(\mathrm{qd}, J=6.5,4.7 \mathrm{~Hz}$, $1 \mathrm{H}), 2.79(\mathrm{dd}, J=16.4,14.7 \mathrm{~Hz}, 1 \mathrm{H}), 2.36(\mathrm{dd}, J=$ $16.7,3.2 \mathrm{~Hz}, 1 \mathrm{H}), 1.68$ (d, $J=1.2 \mathrm{~Hz}, 3 \mathrm{H}), 1.30$ (d, $J$ $=6.5 \mathrm{~Hz}, 3 \mathrm{H}) .{ }^{13} \mathrm{C} \mathrm{NMR}$ (d $\mathrm{d}_{6}$-acetone): $\delta \square=193.1$, 160.3, 140.3, 129.6, 129.0, 128.8, 114.6, 82.8, 76.3, 72.5, 38.9, 16.1, 11.3; FAB-HRMS $m / z$ 253.1428 (calcd for $\mathrm{C}_{15} \mathrm{H}_{18} \mathrm{O}_{3} \mathrm{Li}\left[\mathrm{M}+\mathrm{Li}^{+}\right] m / z$ 253.1416).

(2R)-2,3-Dihydro-5-methyl-2-[(1S)-1(phenylmethoxy)ethyl]-4H-pyran-4-one (16) and (2S)-2,3-Dihydro-5-methyl-2-[(1S)-1(phenylmethoxy)ethyl]-4H-pyran-4-one ((+)-17).

To a solution of $14(0.932 \mathrm{~g}, 5.67 \mathrm{mmol})$ in anhydrous $\mathrm{CH}_{2} \mathrm{Cl}_{2}(10 \mathrm{~mL})$ at $-78{ }^{\circ} \mathrm{C}$ was added a solution of $\mathrm{BF}_{3} \cdot \mathrm{Et}_{2} \mathrm{O}(1.10 \mathrm{~mL}, 9.07 \mathrm{mmol})$ in anhydrous $\mathrm{CH}_{2} \mathrm{Cl}_{2}(60 \mathrm{~mL})$ was added. After 10 min, a solution of 15 (1.631 g, $8.505 \mathrm{mmol})$ in anhydrous $\mathrm{CH}_{2} \mathrm{Cl}_{2}(10 \mathrm{~mL})$ was added. The reaction mixture was slowly allowed to warm to room temperature over $18 \mathrm{~h}$ and then worked up with TFA 
in a fashion similar to the preparation of 17 . The residue was purified by column chromatography $\left(\mathrm{SiO}_{2}\right.$, hexanes-ethyl acetate $\left.=3: 1\right)$, to afford an inseparable mixture of $\mathbf{1 6}$ and 17 (1.6:1) as determined by ${ }^{1} \mathrm{H}$ NMR spectroscopy. ${ }^{1} \mathrm{H}$ NMR $\left(\mathrm{CDCl}_{3}\right)$ (in addition to the signals reported above for 17, the following signals were assigned to 16) $\delta$ 7.39-7.27 (m, 6H), $4.67(\mathrm{~d}, J=11.7 \mathrm{~Hz}, 1 \mathrm{H}), 4.59$ $(\mathrm{d}, J=12.0 \mathrm{~Hz}, 1 \mathrm{H}), 4.33$ (ddd, $J=14.4,3.8,3.8 \mathrm{~Hz}$, $1 \mathrm{H}), 3.81(\mathrm{qd}, J=6.5,4.1 \mathrm{~Hz}, 1 \mathrm{H}), 2.68(\mathrm{dd}, J=$ $16.7,14.4 \mathrm{~Hz}, 1 \mathrm{H}), 2.56(\mathrm{dd}, J=16.7,3.5 \mathrm{~Hz}, 1 \mathrm{H})$, $1.70(\mathrm{~d}, J=1.2 \mathrm{~Hz}, 3 \mathrm{H}), 1.27(\mathrm{~d}, J=6.5 \mathrm{~Hz}, 3 \mathrm{H})$. ${ }^{13} \mathrm{C}$ NMR $\left(\mathrm{CDCl}_{3}\right) \delta 192.3,158.7,137.7,128.1$, $127.5,127.3,113.7,82.1,75.2,71.7,37.6,16.4$, 11.3.

3,7-Anhydro-1,4,6-trideoxy-6-methyl-2-O(phenylmethyl)-D-xylo-hept-6-enitol ((+)-20).

To a solution of $17(6.190 \mathrm{~g}, 25.16 \mathrm{mmol})$ in benzene $(370 \mathrm{~mL})$ cooled to $0{ }^{\circ} \mathrm{C}$ was added a solution of DIBAL $(50.0 \mathrm{~mL}, 1.0 \mathrm{M}$ in hexanes, 50 $\mathrm{mmol})$. The reaction mixture was stirred for $3 \mathrm{~h}$ at 0 ${ }^{\circ} \mathrm{C}$ and then was quenched by the dropwise addition of saturated aqueous $\mathrm{NaHCO}_{3}$ solution $(200 \mathrm{~mL})$. The layers were separated and the aqueous layers were extracted several times with ethyl acetate. The organic layers were dried $\left(\mathrm{MgSO}_{4}\right)$, filtered through celite in a sintered glass funnel, and concentrated. The residue was purified by chromatography $\left(\mathrm{SiO}_{2}\right.$, hexanes-ethyl acetate $=4: 1)$ to give $(+)-\mathbf{2 0}(5.48 \mathrm{~g}$, $88 \%$ ) as a colorless solid: $\mathrm{mp} 48-50{ }^{\circ} \mathrm{C} ;[\alpha]_{\mathrm{D}}{ }^{23}+18$ (c $0.214 \mathrm{CHCl}_{3}$ ). IR (KBr): 3231, 2955, 2880, 1667, 1497, 1454, 1372, 1350, 1057, $981 \mathrm{~cm}^{-1}$. ${ }^{1} \mathrm{H} \mathrm{NMR}$ $\left(\mathrm{CDCl}_{3}\right): \delta=7.36-7.27(\mathrm{~m}, 5 \mathrm{H}), 6.19(\mathrm{~s}, 1 \mathrm{H}), 4.66$ $(\mathrm{d}, J=12.0 \mathrm{~Hz}, 1 \mathrm{H}), 4.54(\mathrm{~d}, J=12.0 \mathrm{~Hz}, 1 \mathrm{H}), 4.27$ $(\mathrm{dd}, J=13.2,7.6 \mathrm{~Hz}, 1 \mathrm{H}), 3.94(\mathrm{ddd}, J=11.1,4.7$, $2.4 \mathrm{~Hz}, 1 \mathrm{H}), 3.64(\mathrm{qd}, J=6.3,4.7 \mathrm{~Hz}, 1 \mathrm{H}), 2.19$ (ddd, $J=13.2,6.5,2.4 \mathrm{~Hz}, 1 \mathrm{H}), 1.82$ (ddd, $J=13.2$, $11.0,8.9 \mathrm{~Hz}, 1 \mathrm{H}), 1.61(\mathrm{~s}, 3 \mathrm{H}), 1.52(\mathrm{~d}, J=7.3 \mathrm{~Hz}$, $1 \mathrm{H}), 1.23(\mathrm{~d}, J=6.5 \mathrm{~Hz}, 3 \mathrm{H}) ;{ }^{13} \mathrm{C} \mathrm{NMR}\left(\mathrm{CDCl}_{3}\right)$ : $\delta \square=140.3,138.5,128.5,127.9,127.7,111.6,77.2$, 75.5, 71.5, 66.0, 33.9, 15.6, 14.1. Anal. calcd for $\mathrm{C}_{15} \mathrm{H}_{20} \mathrm{O}_{3}: \mathrm{C}, 72.55 ; \mathrm{H}, 8.12$. Found: C, 72.29; H, $7.87 \%$.

$(2 R, 6 S)-2-E t h y l-5,6-d i h y d r o-3-m e t h y l-6-[(1 S)-$ 1-phenylmethoxy)ethyl]-2H-pyran ((-)-21)

To a solution of $20(2.691 \mathrm{~g}, 10.85 \mathrm{mmol})$ in anhydrous $\mathrm{CH}_{2} \mathrm{Cl}_{2}(210 \mathrm{~mL})$, cooled to $-40{ }^{\circ} \mathrm{C}$, was added a solution of triethylaluminum $(2.2 \mathrm{~mL}, 1.0 \mathrm{M}$ in hexanes, $0.037 \mathrm{~mol}$,), followed by $\mathrm{BF}_{3} \cdot \mathrm{Et}_{2} \mathrm{O}(1.4$ $\mathrm{mL}, 0.011 \mathrm{~mol})$. The reaction mixture was stirred at $-40{ }^{\circ} \mathrm{C}$ for $3 \mathrm{~h}$ and at $0{ }^{\circ} \mathrm{C}$ for $1.5 \mathrm{~h}$ and then was quenched with saturated aqueous sodium potassium tartrate solution $(100 \mathrm{~mL})$. The biphasic reaction mixture was allowed to warm to room temperature, the layers were separated, and the aqueous layer was extracted several times with $\mathrm{CH}_{2} \mathrm{Cl}_{2}$. The organic layers were dried $\left(\mathrm{MgSO}_{4}\right)$ and concentrated giving the crude material as a 1:8 ratio of cis and trans isomers. Separation of this crude mixture by column chromatography $\left(\mathrm{SiO}_{2}\right.$, hexanes-ethyl acetate $\left.=75: 1\right)$ afforded pure (-)-21 (2.121 g, 75\%) as a colorless oil; $[\alpha]_{\mathrm{D}}{ }^{23}-70\left(\mathrm{c}=0.26, \mathrm{CHCl}_{3}\right)$. IR (neat): 2973, 2875, 1741, 1497, 1454, 1374, 1207, 1101, 1050, $967 \mathrm{~cm}^{-1} ;{ }^{1} \mathrm{H}$ NMR $\left(\mathrm{CDCl}_{3}\right): \delta=7.40-7.22(\mathrm{~m}, 5 \mathrm{H})$, 5.46 (ddd, $J=3.5,1.8,1.8 \mathrm{~Hz}, 1 \mathrm{H}), 4.67(\mathrm{~s}, 2 \mathrm{H})$, $3.89(\mathrm{dd}, J=6.7,6.7 \mathrm{~Hz}, 1 \mathrm{H}), 3.62(\mathrm{qd}, J=5.6,3.5$ $\mathrm{Hz}, 1 \mathrm{H}$ ), 3.53 (ddd, $J=12.0,6.4,6.4 \mathrm{~Hz}, 1 \mathrm{H}$ ), 2.12 (dddd, $J=17.0,10.6,4.7,2.3 \mathrm{~Hz}, 1 \mathrm{H}), 1.86-1.74(\mathrm{~m}$, $1 \mathrm{H}), 1.66-1.54(\mathrm{~m}, 5 \mathrm{H}), 1.20(\mathrm{~d}, J=6.5 \mathrm{~Hz}, 3 \mathrm{H})$, $1.05(\mathrm{t}, J=7.3 \mathrm{~Hz}, 3 \mathrm{H}) ;{ }^{13} \mathrm{C}$ NMR $\left(\mathrm{CDCl}_{3}\right)$ : $\delta=139.3,136.5,128.5,128.1,127.6,119.0,78.5$, 77.9, 72.3, 70.6, 27.5, 24.8, 20.5, 16.5, 11.4; FABHRMS $m / z$ 267.1941 (calcd for $\mathrm{C}_{17} \mathrm{H}_{24} \mathrm{O}_{2} \mathrm{Li}\left[\mathrm{M}+\mathrm{Li}^{+}\right]$ $\mathrm{m} / \mathrm{z}$ 267.1936).

$(\alpha S, 2 S, 6 R)$-6-Ethyl-3,6-dihydro- $\alpha, 5$-dimethyl2H-pyran-2-methanol ((-)-22).

In a two necked flask cooled to $-78{ }^{\circ} \mathrm{C}$ was condensed ammonia $(30 \mathrm{~mL})$. A solution of $\mathbf{2 1}$ $(1.003 \mathrm{~g}, 3.858 \mathrm{mmol})$ in THF $(15 \mathrm{~mL})$ was added, followed by the careful slow addition of small pieces of sodium metal until the reaction became and remained blue in color $(1.495 \mathrm{~g}, 6.173 \mathrm{mmol})$. The reaction mixture was stirred under $\mathrm{N}_{2}$ for $2.5 \mathrm{~h}$. Solid $\mathrm{NH}_{4} \mathrm{Cl}$ (4.186 g, $78.26 \mathrm{mmol}$ ) was then added portion-wise until the reaction mixture became colorless. The cooling bath was removed and the ammonia was slowly allowed to evaporate under $\mathrm{N}_{2}$. After the ammonia has completely evaporated, THF (20 $\mathrm{mL})$ was added followed by the drop-wise addition of isopropanol $(5 \mathrm{~mL})$ and water $(50 \mathrm{~mL})$. The layers were separated and the aqueous layer was extracted several times with ethyl acetate. The organic layers were dried $\left(\mathrm{MgSO}_{4}\right)$, concentrated, and the crude oil was purified by chromatography $\left(\mathrm{SiO}_{2}\right.$, ethyl acetate-hexanes $=0 \rightarrow 20 \%$ gradient $)$ affording (-)-22 (0.528 g, 81\%) as a colorless oil; $[\alpha]_{\mathrm{D}}^{23}-78.4\left(\mathrm{c} 0.340, \mathrm{CHCl}_{3}\right)$. IR (neat): 3465,2972 , 2932, 2875, 1453, 1367, 1261, 1107, 1042, 926, 891 $\mathrm{cm}^{-1} .{ }^{1} \mathrm{H} \mathrm{NMR}\left(\mathrm{CDCl}_{3}\right): \delta=5.46(\mathrm{ddd}, J=6.2,2.9$, $1.5 \mathrm{~Hz}, 1 \mathrm{H}), 3.87$ (dd, $J=7.0,6.5 \mathrm{~Hz}, 1 \mathrm{H}), 3.62$ (qd, $J=7.2,6.5 \mathrm{~Hz}, 1 \mathrm{H}), 3.36(\mathrm{ddd}, J=9.1,7.6,5.3 \mathrm{~Hz}$, $1 \mathrm{H}), 1.96-1.88(\mathrm{~m}, 2 \mathrm{H}), 1.67-1.55(\mathrm{~m}, 5 \mathrm{H}), 1.16(\mathrm{~d}, J$ $=6.5 \mathrm{~Hz}, 3 \mathrm{H}), 1.03(\mathrm{t}, J=7.3 \mathrm{~Hz}, 3 \mathrm{H})$; signal for $\mathrm{OH}$ not observed. ${ }^{13} \mathrm{C} \mathrm{NMR}\left(\mathrm{CDCl}_{3}\right): \delta \square=136.2$, 118.3, 78.2, 71.5, 70.7, 27.5, 24.5, 20.2, 18.3, 11.3. EI-HRMS $m / z, 170.1311$ (calcd for $\mathrm{C}_{10} \mathrm{H}_{18} \mathrm{O}_{2} \mathrm{~m} / \mathrm{z}$ 170.1307).

\section{1-((2S,6R)-6-Ethyl-3,6-dihydro-5-methyl-2H-} pyran-2-yl)ethanone ((-)-23)

To a solution of $22(1.222 \mathrm{~g}, 7.188 \mathrm{mmol})$ in anhydrous DMF $(80 \mathrm{~mL})$ was added pyridinium dichromate $(13.491 \mathrm{~g}, 35.880 \mathrm{mmol})$. The reaction mixture was stirred at room temperature for $18 \mathrm{~h}$ and was then partitioned between ether and water. The layers were separated, the aqueous layer was extracted several times with ether, and the combined organic layers were dried $\left(\mathrm{MgSO}_{4}\right)$ and concentrated. The crude oil was adsorbed onto silica and purified 
by chromatography $\left(\mathrm{SiO}_{2}\right.$, hexanes-ethyl acetate $=8: 1)$ to give $(-)-23(0.971 \mathrm{~g}, 80 \%)$ as a colorless oil; $[\alpha]_{\mathrm{D}}{ }^{23}-129.2$ (c $\left.0.3320, \mathrm{CHCl}_{3}\right)$. IR (neat): 2967 , 2934, 2876, 1717, 1453, 1355, 1120, 1053, $924 \mathrm{~cm}^{-1}$. ${ }^{1} \mathrm{H}$ NMR $\left(\mathrm{CDCl}_{3}\right): \delta=5.49(\mathrm{ddd}, J=6.2,3.5,1.8$ $\mathrm{Hz}, 1 \mathrm{H}), 4.06$ (dd, $J=7.9,5.9 \mathrm{~Hz}, 1 \mathrm{H}), 4.00$ (br d, $J$ $=9.7 \mathrm{~Hz}, 1 \mathrm{H}), 2.24(\mathrm{~s}, 3 \mathrm{H}), 2.22-2.14(\mathrm{~m}, 2 \mathrm{H}), 1.70$ (s, 3H), 1.74-1.49 (m, 2H), $1.02(\mathrm{t}, J=7.3 \mathrm{~Hz}, 3 \mathrm{H})$; ${ }^{13} \mathrm{C} \mathrm{NMR}\left(\mathrm{CDCl}_{3}\right): \delta=209.6,136.0,118.1,78.1$, 73.3, 26.8, 26.2, 24.7, 20.1, 10.7; EI-HRMS m/z 168.1150 (calcd for $\mathrm{C}_{10} \mathrm{H}_{16} \mathrm{O}_{2} \mathrm{~m} / z$ 168.1136).

1-((2R, 6R)-6-Ethyl-3, 6-dihydro-5-methyl2H-pyran-2-yl)ethanone ((+)-4)

To a solution of $\mathbf{2 3}(0.911 \mathrm{~g}, 5.35 \mathrm{mmol})$ in benzene $(50 \mathrm{~mL})$ was added methanolic potassium carbonate $(5 \mathrm{~mL})$. The reaction mixture became bright yellow in color and was stirred at room temperature for $63 \mathrm{~h}$. The reaction mixture was then washed with $1.0 \underline{\mathrm{M} \mathrm{HCl}}(2 \times 100 \mathrm{~mL})$ and extracted several times with ether. The organic layers were dried $\left(\mathrm{MgSO}_{4}\right)$ and concentrated affording a mixture of diastereomers $\mathbf{4}$ and $23\left(2: 1\right.$ by ${ }^{1} \mathrm{H}$ NMR integration). Separation of the mixture by column chromatography $\left(\mathrm{SiO}_{2}\right.$, hexanes-ethyl acetate $\left.=75: 1\right)$ gave $4(0.562 \mathrm{~g}, 62 \%)$ followed by $23(0.330 \mathrm{~g}$, $36 \%$ ). The recovered 23 isomer was resubjected to the above epimerization-separation procedure. $(+)-\mathbf{4}$ : $[\alpha]_{\mathrm{D}}{ }^{23}+172\left(\mathrm{c} 0.248, \mathrm{CHCl}_{3}\right) \quad\left[\right.$ lit. $^{9}[\alpha]_{\mathrm{D}}+191.7$ (c $\left.1.57, \mathrm{CHCl}_{3}\right)$; lit. ${ }^{10}[\alpha]_{\mathrm{D}}{ }^{20}+181\left(\mathrm{c} 0.257, \mathrm{CDCl}_{3}\right)$,]; IR (neat): 2966, 2936, 2879, 1721, 1435, 1352, 1229 , 1116, 1058, $927 \mathrm{~cm}^{-1} ;{ }^{1} \mathrm{H} \mathrm{NMR}\left(\mathrm{CDCl}_{3}\right): \delta=5.60-$ $5.33(\mathrm{~m}, 1 \mathrm{H}), 4.13-4.05(\mathrm{~m}, 1 \mathrm{H}), 3.92(\mathrm{dd}, J=10.4$, $4.4 \mathrm{~Hz}, 1 \mathrm{H}), 2.25(\mathrm{~s}, 3 \mathrm{H}), 2.21-2.00(\mathrm{~m}, 2 \mathrm{H}), 1.81$ (ddq, $J=14.9,10.9,3.5 \mathrm{~Hz}, 1 \mathrm{H}), 1.60(\mathrm{ddd}, J=2.4$, $2.4,1.4 \mathrm{~Hz}, 3 \mathrm{H}), 1.54(\mathrm{ddq}, J=14.1,7.0,7.0 \mathrm{~Hz}$, $1 \mathrm{H}), 0.95(\mathrm{t}, J=7.3 \mathrm{~Hz}, 3 \mathrm{H}) ;{ }^{13} \mathrm{C} \mathrm{NMR}\left(\mathrm{CDCl}_{3}\right)$ : $\delta=210.0,135.7,119.7,79.0,78.5,27.6,26.1,25.9$, 19.2, 9.0.

\section{References}

1 - D. T. Connor, R. C. Greenough and M. von Strandtmann, M. J. Org. Chem. 1977, 42, 36643669.

2 - K. Gerth, P. Washausen, G. Höftle, H. Irschik and H. Reichenbach, J. Antibiotics 1996, 49, 71-75.

3 - B. Julien, Z. Q. Tian, R. Reid and C. D. Reeves, Chemistry \& Biology 2006, 13, 1277-1286.

4 - a) G. Just and P. Potvin, Can. J. Chem. 1980, 58, 2173-2177; b) N. J. Barnes, A. H. Davidson, L. R. Hughes, G. Procter and V. Rajcoomar, Tetrahedron Lett. 1981, 22, 1751-1754; c) N. J. Barnes, A. H. Davidson, L. R. Hughes and G. Procter, J. Chem. Soc., Chem. Comm. 1985, 1292-1294; d) G. Proctor, A. T. Russell, P. J. Murphy, P. J. Tan and A. N. Mather, Tetrahedron 1988, 44, 3953-3973; e) A. H. Davidson, H. Eggleton and I. H. Wallace, J. Chem. Soc., Chem. Commun. 1991, 378-380; f) I. E. Marko and D. J. Bayston, Tetrahedron 1994, 50, 7141-7156; g) I. E. Marko and D. J. Bayston, Synthesis 1996, 297-304; h) H. Wakamatsu, N. Isono and M. Mori, J. Org. Chem. 1997, 62, 8917-8922; i) P. Varelis and B. L. Johnson, Aust. J. Chem. 1997, 59, 43-51; j) V. Michelet, K. Adiey, B. Bulic, J. P. Genet, G. Dujardin, S. Rossignol, E. Brown and L. Toupet, Eur. J. Org. Chem. 1999, 2885-2892; k) J. Yin, I. Llorente, L. A. Villanueva and L. S. Liebeskind, J. Am. Chem. Soc. 2000, 122, 10458-10459; 1) I. Marko, T. Kumamoto and T. Giard, Adv. Synth. Catal. 2002, 1063-1067; m) V. Michelet, K. Adiey, S. Tanier, G. Dujardin and J. P. Genet, Eur. J. Org. Chem. 2003, 2947-2958.

5 - a) A. S. Kende, J. S. Mendoza and Y. Fujii, J. Am. Chem. Soc. 1990, 112, 9645-9646; b) A. S. Kende, J. S. Mendoza and Y. Fujii, Tetrahedron 1993, 49, 8015-8038.

6 - P. Liu and E. N. Jacobsen, J. Am. Chem. Soc. 2001, 123, 10772-10773.

7 - a) T. A. Kirkland, J. Colucci, L. S. Geraci, M. A. Marx, K. Schneider, D. E. Kaelin, Jr. and S. F. Martin, J. Am. Chem. Soc. 2001, 123, 12432-12433; b) S. M. Beberich, R. J. Cherney, J. Colucci, C. Courillon, L. S. Geraci, T. A. Kirkland, M. A. Marx, M. Schneider and S. F. Martin, Tetrahedron 2003, 59, 6819-6832.

8 - E. Lee, S. J. Choi, H. Kim, H. O. Han, Y. K. Kim, S. J. Min, S. H. Son, S. M. Lim and W. S. Jang, Angew. Chem. Int. Ed. 2002, 41, 176-177.

9 - S. Hanessian, T. Focken, X. Mi, R. Oza, B. Chen, D. Riston and R. Beaudegnies, J. Org. Chem. 2010, 75, 5601-5618.

10 - J. Pospisil and I. E. Marko, J. Am. Chem. Soc. 2007, 129, 3516-3517.

11 - S. Hanessian, T. Focken and R. Oza, Org. Lett. 2010, 12, 3172-3175.

12 - a) L. Liu and W. Donaldson, Synlett 1996, 103-104; b) J. M. Lukesh and W. Donaldson, Tetrahedron Lett. 2005, 46, 5529-5531.

13 - a) M. D. Lewis, J. K. Cha and Y. Kishi, J. Am. Chem. Soc. 1982, 104, 4976-4978; b) S. J. Danishefsky and J. F. Kerwin, Jr., J. Org. Chem. 1982, 47, 3803-3805; c) A. Hosomi, Y. Sakata and H. Sakuri, Tetrahedron Lett. 1984, 25, 2383-2386; d) K. Maruoka, K. Nonoshita, T. Itoh and H. Yamamoto, Chem. Lett. 1987, 2215-2216; e) for a recent review see: A. M. Gomez, F. Lobo, C. Uriel and J. C. Lopez, Eur. J. Org. Chem. 2013, 7221-7262. 
14 - For a discussion of the effects of pyranyl substitutents on the stereoselectivity of C-glycosylation see: C. G. Lucero and K. A. Woerpel, J. Org. Chem. 2006, 71, 2641-2647.

15 - a) S. Danishefsky and M. T. Bilodeau, Angew. Chem., Int. Ed. 1996, 35, 1380-1419; b) S. J. Danishefsky, Aldrichimica Acta 1986, 19, 59-69.

16 - G. Solladie, E. Arce, C. Bauder and M. C. Carreno, J. Org. Chem. 1998, 63, 2332-2337.

17 - D. C. Myles and M. H. Bigham, Org. Syn. 1992, 70, 231-239.

18 - S. J. Danishefsky, W. H. Pearson, D. F. Harvey, C. J. Maring and J. P. Springer, J. Am. Chem. Soc. 1985, 107, 1256-1268.
19 - a) P. P. Deshpande, K. N. Price and D. C. Baker, J. Org. Chem. 1996, 61, 455-458; b) J. M. Lukesh and W. A. Donaldson, Tetrahedron: Asymmetry, 2003, 14, 757-762; c) S. Xue, L. He, K. Z. Han, X. Q. Zheng and Q. X. Guo, Carbohyd. Res. 2005, 340, 303-307; d) P. Deelertpaiboon, V. Reutrakul, S. Jarussophon, P. Tuchinda, C. Kuhakarn and M. Pohmakotr, Tetrahedron Lett. 2009, 50, 6233-6235.

20 - A. Nowacki, K. Smiataczowa, R. Kasprzykowska, B. Dmochowska and A. Wisniewski, Carbohyd. Res. 2002, 337, 265-272. 